\title{
60 years of Cimicifuga racemosa medicinal products
}

\section{Clinical research milestones, current study findings and current development}

\author{
Hans-Heinrich Henneicke-von Zepelin
}

Received: 7 October 2016 / Accepted: 15 December 2016 / Published online: 2 February 2017 (C) The Author(s) 2017. This article is available at SpringerLink with Open Access.

\begin{abstract}
Summary Cimicifuga racemosa (CR) extracts are important worldwide as therapy for menopausal symptoms. The first medicinal product from CR has been available since 1956 (Germany, Remifemin ${ }^{\circledR}$ [Schaper \& Brümmer, Salzgitter, Germany], isopropanolic extract iCR). This review describes how CR developed, via clinical studies on safety (breast, breast cancer, endometrium, liver) and efficacy, into a successful and safe medicinal product in Germany, Europe and the world. In line with developing legal frameworks for medicinal products in Germany and Europe, clinical studies on CR were observational during the 50 s and $70 \mathrm{~s}$, and controlled studies since the 80s. The first placebo-controlled study emerged 1986. From 2000 to 2015, a total of 28 clinical studies in Europe, America and Asia were published on the efficacy of CR. In these studies, 11,073 patients received a CR-based medicinal product, $93 \%$ thereof iCR. A meta-analysis of all nine placebo-controlled studies published until 2013 confirmed the reliable efficacy of CR-based medicinal products for menopausal symptoms.
\end{abstract}

Keywords Climacteric complaints - Cimicifuga racemosa $\cdot$ Actaea racemosa $\cdot$ Black Cohosh $\cdot$ Survival after breast cancer · Osteoporosis · Myoma · Cognition

\section{Jahre Arzneimittel aus Cimicifuga racemosa}

Meilensteine klinischer Forschung, aktuelle Studienergebnisse und derzeitige Entwicklung

Zusammenfassung Extrakte aus Cimicifuga racemosa (CR) haben zur Therapie von Wechseljahresbeschwer-

Dr. H.-H. Henneicke-von Zepelin $(\bowtie)$

Clinical Research, Schaper \& Brümmer GmbH \& Co. KG, Bahnhofstraße 35, 38259 Salzgitter, Germany

h.v.zepelin@schaper-bruemmer.de den weltweit an Bedeutung gewonnen. Das erste aus CR hergestellte Fertigarzneimittel steht seit 1956 zur Verfügung (Deutschland, Remifemin ${ }^{\circledR}$ [Schaper \& Brümmer, Salzgitter, Deutschland], isopropanolischer Extrakt aus CR, iCR). Diese Übersichtsarbeit beschreibt, wie sich CR durch klinische Studien zur Sicherheit (Brust, Brustkrebs, Endometrium, Leber) und Wirksamkeit zu einem erfolgreichen und sicheren Arzneimittel in Deutschland, Europa und weltweit entwickelt hat. In Übereinstimmung mit der jeweiligen Entwicklung der gesetzlichen Rahmenbedingungen zu Arzneimitteln wurden klinische Studien zu CR in den 1950er- und 1970er- Jahren als beobachtende Studien durchgeführt. Seit den 1980er-Jahren folgten kontrollierte Studien, darunter die erste placebokontrollierte Studie 1986. Von 2000 bis 2015 wurden insgesamt 28 klinische Studien aus Europa, Amerika und Asien zur Wirksamkeit von CR veröffentlicht. In diesen Studien erhielten 11.073 Patientinnen ein CRArzneimittel, $93 \%$ davon iCR. Eine Metaanalyse aller 9 bis 2013 veröffentlichten placebokontrollierten Studien bestätigte die zuverlässige Wirksamkeit von CRArzneimitteln gegen Wechseljahresbeschwerden.

Schlüsselwörter Wechseljahresbeschwerden · Cimicifuga racemosa - Actaea racemosa . Traubensilberkerze · Überleben nach Brustkrebs · Osteoporose · Myom · Kognition

\section{Short Overview}

Approximately four out of five women suffer from menopausal symptoms (MPS) such as hot flushes and sweating, as well as from sleep disorders associated with these symptoms. Many women also suffer from psychological symptoms such as mood disorders, nervousness and irritability. For decades, extracts made from the rhizome of Cimicifuga race- 
mosa (L.) Nutt. (CR, synonym for Actaea racemosa L., 'Traubensilberkerze', black cohosh) have been gaining worldwide importance as therapy for MPS. This herbal substance was originally used in North American folk medicine. The first medicinal product produced from black cohosh has been available since 1956 (Germany, Remifemin ${ }^{\circledR}$ [Schaper \& Brümmer, Salzgitter, Germany], isopropanolic extract iCR). At about the same time, Kupperman established his Menopause Index (KMI), which has since been used in numerous clinical studies with CR. From the 50s to the 70s, clinical research on CR followed the common practice of documenting and publishing clinical experiences. The German Medicines Act from 1976 enacted the obligation to provide proof of efficacy. Appropriately, controlled clinical trials followed in the 80s. From 1985 to 1987 , the German Ministry of Health established standards on how to conduct clinical trials for drugs, i. e. medicinal products. Accordingly, the first randomized, placebo-controlled clinical trial with any CR extract was conducted (1986, iCR, KMI, Germany).

Good Clinical Practice (GCP) first came into effect in 1991 and was harmonized by the International Conference of Harmonization (ICH) in 1996. In 1994, Hauser published his Menopause Rating Scale (MRS) as a new tool to measure menopausal symptoms. A factor analysis established four MRS-I subscores in 2000; a self-assessment version appeared as MRS-II and is meanwhile available in 27 languages.

The first GCP compliant clinical study with CR in 1995 was dedicated to the question of dose-efficacy relationship (KMI, Poland). Daily doses of iCR extract from up to $127 \mathrm{mg}$ CR proved to be safe. Without differentiating according to menopausal status, $40 \mathrm{mg}$ already showed sufficient efficacy. However, perimenopausal women profited more from $127 \mathrm{mg}$ than from $40 \mathrm{mg}$.

The second placebo-controlled clinical study for iCR followed from 2002 to 2005 (MRS, Germany). In addition to proof of efficacy, factors that influence efficacy were revealed and the first subtle hints of a suprahypothalamic CNS (central nervous system) influence were found.

In 2003, the first placebo-controlled study with a Cimicifuga product from an ethanolic extract (Klimadynon $^{\circledast}$ [Bionorica, Neumarkt, Germany]) was published. The study strengthens the MRS by establishing the MRS-based effect size of hormone therapy (HT) for MPS compared to placebo (Czech Republic).

Controlled studies comparing iCR with other MPS therapies showed no differences in efficacy compared to hormone patches (2005, Italy) and tibolone, but iCR was superior regarding safety (2007, China). Another CR product (Remixin ${ }^{\circledR}$ [Mikro-Gen, Istanbul, Turkey]) was compared to fluoxetine, with inferiority in the psychological component of the MPS and superiority in the KMI (2008, Turkey).

In 2005/2008, a clinical study clinically proved a CNS influence of iCR using positron emission tomog- raphy (USA). This is consistent with the pathophysiological tests in which CNS cortical activation accompanied menopausal hot flushes (2006, USA).

To date, the largest clinical study with CR ( $n=6141$, Germany) was published 2005/2007 and, for the first time, included over 12 months of safety data on patients $(n=736)$. iCR was compared with a combined product containing iCR and St. John's wort (HP). iCRHP showed an additional benefit on the psychological component of MPS. Proof of efficacy for this combination was also obtained using a placebo-controlled study (2006, MRS, Germany).

In 2006, a clinical study on safety at the endometrium with a 12-month CR therapy followed (Poland, Czech Republic).

The safety of iCR on breast tissue (mammography and fine-needle aspiration biopsy) was also substantiated with a clinical study: in 2007 alone, and in 2011 in a meta-analysis comparison with placebo, HT and tibolone (Sweden). Additionally, a pharmacoepidemiological cohort study demonstrated a 4.5-year longer recurrence-free survival after breast cancer for iCR users (2007, Germany).

In 2010, the Herbal Medicinal Product Committee (HMPC) of the European Medicinal Agency monograph attested the well-established use of drugs containing CR extract based on previously published studies on menopausal symptoms. According to the HMPC, there is no limit on the length of use, but after 6 months of therapy, a medical professional should be consulted. Breast cancer patients are not excluded from treatment of MPS with CR as long as a medical professional is consulted.

In 2011 the first meta-analysis was dedicated to the topic of liver safety. Of all five controlled clinical studies with iCR available at the time, the liver function test values were summarized where they had been raised. Evidence of liver toxicity was not found (international).

From 2000 to 2015, a total of 28 clinical studies in Europe, America and Asia were published on the efficacy of CR. In these studies, 11,073 patients received a CR drug, 93\% thereof iCR. In 2013 a corrective reply to a Cochrane report on CR presented a complete meta-analysis of all nine placebo-controlled studies published until then; the report confirmed the reliable efficacy of CR drugs (international).

A recent study analysis evidenced that in women who were treated with iCR for MPS, myomas shrank in size compared to therapy with tibolone (2014, China). The latest placebo-controlled clinical study with iCR came from China. It showed improvement in sleep quality.

Future CR research may be dedicated to such topics as: mechanisms of action, possible extension of indications (e.g. prophylaxis for breast cancer recurrence) or additional uses (e.g. improvement of osteoporosis fractures or cognitive abilities). To date, the results of clinical research with CR confirm its safety and 
efficacy for menopausal symptoms and also provide valuable insights into additional uses, mechanisms of action and more.

\section{Kurzübersicht}

Etwa 4 von 5 Frauen leiden während ihrer Wechseljahre an Beschwerden (WJB) wie Hitzewallungen, Schweißausbrüchen und damit assoziierten Schlafstörungen, etliche zusätzlich an psychischen Symptomen wie Verstimmungszuständen, Nervosität und Reizbarkeit. Seit Jahrzehnten gewinnt deren Therapie mit Extrakten aus dem Wurzelstock von Cimicifuga racemosa (L.) Nutt. (CR, synonym für Actaea racemosa L., Traubensilberkerze, Black Cohosh) weltweit an Bedeutung. Diese Arzneidroge stammt ursprünglich aus der Volksmedizin Nordamerikas. Das erste hieraus hergestellte Fertigarzneimittel steht seit 1956 zur Verfügung (Deutschland, Remifemin ${ }^{\circledast}$ [Schaper \& Brümmer, Salzgitter, Deutschland], isopropanolischer Extrakt, iCR). Etwa zeitgleich etablierte Kupperman seinen Menopause-Index (KMI, 1953-1959), der seither in diversen klinischen Studien zu CR eingesetzt wurde. In den 1950er- bis 1970er- Jahren folgte die klinische Forschung zu CR dem damals üblichen Vorgehen, dem Dokumentieren und Veröffentlichen von klinischen Erfahrungswerten. Das Arzneimittelgesetz 1976 führte die Pflicht zum Nachweis der Wirksamkeit ein, entsprechende kontrollierte klinische Studien folgten in den 1980er- Jahren. Das BMJFFG (Bundesministerium für Jugend, Familie, Frauen und Gesundheit) erließ 1985-1987 Grundsätze für die Durchführung der klinischen Prüfung von Arzneimitteln. Entsprechend wurde die erste randomiserte placebokontrollierte klinische Prüfung zu CR durchgeführt (1986, iCR, KMI, Deutschland).

Good Clinical Practice (GCP) trat erstmals 1991 und dann 1996 ICH-harmonisiert, also gemäß International Conference(s) of Harmonization, in Kraft. Hauser veröffentlichte 1994 seine Menopause Rating Scale MRS als neues Messinstrument von Wechseljahresbeschwerden, für die 2000 eine Faktorenanalyse die MRS-I-Subskalen etablierte und eine Selbstbeurteilungsvariante als MRS-II erschien, in mittlerweile 27 Sprachen verfügbar.

Die erste GCP-konforme klinische Studie zu CR widmete sich 1995 der Fragestellung zur Dosis-Wirksamkeits-Beziehung (KMI, Polen). Tagesdosen an iCR-Extrakt aus bis zu $127 \mathrm{mg}$ CR erwiesen sich als sicher. Ohne Differenzierung nach Menopausestatus waren bereits $40 \mathrm{mg}$ ausreichend wirksam. Doch perimenopausale Frauen profitierten von $127 \mathrm{mg}$ mehr als von $40 \mathrm{mg}$.

In den Jahren 2002-2005 folgte die zweite placebokontrollierte klinische Prüfung zu iCR (MRS, Deutschland). Neben dem Wirksamkeitsbeleg arbeitete sie Einflussgrößen auf die Wirksamkeit heraus und ergab erste Hinweise auf einen suprahypothalamischen ZNS-Einfluss von iCR.

Die erste placebokontrollierte Studie $\mathrm{zu}$ einem Cimicifuga-Produkt mit einem ethanolischen Extrakt wurde 2003 publiziert (Klimadynon ${ }^{\circledast}$ [Bionorica, Neumarkt, Deutschland]). Sie etablierte die MRS-basierte Effektgröße einer Hormontherapie der WJB im Vergleich zu Placebo und CR (Tschechien).

Kontrollierte Studien zum Vergleich von iCR mit anderen WJB-Therapien ergaben keinen Wirksamkeitsunterschied zu Hormonpflastern (2005, Italien) und zu Tibolon bei gleichzeitiger Überlegenheit in puncto Sicherheit (2007, erstmals China). Ein weiteres CRProdukt (Remixin ${ }^{\circledast}$ [Mikro-Gen, Istanbul, Türkei]) steuerte 2008 eine kontrollierte Studie im Vergleich zu Fluoxetin bei, mit Unterlegenheit in der psychischen Komponente der WJB und Überlegenheit im KMI (Türkei).

Eine klinische Studie belegte 2005/2008 den den ZNS-Einfluss von iCR klinisch per Positronenemissionstomographie (USA). Dies ist vereinbar mit pathophysiologischen Untersuchungen, in denen menopausale Hitzewallungen mit ZNS-kortikaler Aktivierung einhergingen (2006, USA).

Die bisher größte klinische Studie zu CR $(n=6141)$ stammt aus 2005 (Deutschland), davon 736 Patientinnen mit Sicherheitsdaten erstmals über 12 Monate. Sie verglich iCR mit einem Kombinationsprodukt aus iCR und Johanniskraut (HP) und zeigte für iCR-HP einen zusätzlichen Benefit-Effekt auf die psychische Komponente der WJB. Auch für diese Kombination erfolgte der Wirksamkeitsbeleg mittels placebokontrollierter Studie (2006, MRS, Deutschland).

Im Jahr 2006 folgte eine klinische Studie zur Sicherheit am Endometrium unter 12-monatiger CR-Therapie (Polen, Tschechien).

Die iCR-Sicherheit am Brustgewebe (Mammographie und Feinnadelbiopsie) wurde auch mittels klinischer Studie untermauert: 2007 allein und 2011 in metaanalytischem Vergleich zu Placebo und Tibolon (Schweden). Zudem ergab eine pharmakoepidemiologische Kohortenstudie ein 4,5 Jahre längeres rezidivfreies Überleben für iCR-Anwenderinnen nach Brustkrebs (2007, Deutschland).

2010 attestierte das HMPC (Herbal Medicinal Product Committee der European Medicinal Agency) per Monographie einen Well Established Use von CRExtrakt-haltigen Arzneimitteln auf Basis der bis dahin publizierten Studien bei WJB. Gemäß HMPC beinhaltet die Anwendungsdauer keine zeitliche Begrenzung, nach 6 Monaten Therapiedauer soll jedoch ärztlicher Rat eingeholt werden. Die Behandlung mit CR von WJB schließt auch Brustkrebspatientinnen nicht aus, sofern ein entsprechender Rat vom Arzt eingeholt wird.

Die erste Metaanalyse widmete sich 2011 dem Thema Lebersicherheit. Sie fasste die Leberfunktionswerte aller 5 bis dahin verfügbaren kontrollierten klinischen Studien zu iCR zusammen, in denen diese 
Table 1 Curriculum vitae. Milestones of clinical research in the career of the first industrial herbal medicinal product containing an extract of Cimicifuga racemosa (CR)

\begin{tabular}{|c|c|c|}
\hline Year & Milestone & Country/region \\
\hline 1956 & Year of birth of Remifemin ${ }^{\circledR}$ & Germany \\
\hline 1956 to 1970 s & Documentation of clinical experiences & Germany \\
\hline 1980s & First randomized controlled clinical trials according to 1976 Medicines Act & Germany \\
\hline 1986 & First placebo-controlled clinical trial on iCR & Germany \\
\hline 1989 & German Commission E monograph on CR & Germany \\
\hline 1991 & Good Clinical Practice & Europe \\
\hline 1995 & First clinical dose-efficacy study & Poland \\
\hline 2003 & First placebo-controlled study on another CR extract; MRS-based effect size of hormone therapy (HT) & Czech Republic \\
\hline 2002 to 2005 & $\begin{array}{l}\text { Second placebo-controlled study on iCR confirms efficacy, identifies confounders influencing the effect size, first } \\
\text { subtle hints of supra-hypothalamic CNS influence }\end{array}$ & Germany \\
\hline 2005 & Controlled study in comparison to hormone patches & Italy \\
\hline $2005 / 2008$ & Clinical evidence on CNS influence of iCR by PET & USA \\
\hline 2007 & Controlled study in comparison to tibolone, first study in China & China \\
\hline 2007 & Clinical study on iCR safety in breast tissue & Sweden \\
\hline 2007 & Pharmacoepidemiological cohort study on recurrence-free survival after breast cancer & Germany \\
\hline 2010 & $\begin{array}{l}\text { Monograph of the Herbal Medicinal Product Committee at the European Medicines Agency concludes well-estab- } \\
\text { lished use of CR-based medicines for alleviating menopausal symptoms, does not limit the duration of use, } \\
\text { allows the use in breast cancer survivors if medically advised }\end{array}$ & Europe \\
\hline 2011 & Meta-/reanalytic safety comparison of iCR with placebo, tibolone and HT regarding breast density & Sweden \\
\hline 2011 & Meta-analysis on liver safety & Europe, China \\
\hline 2005 to 2015 & More clinical studies on iCR in Europe, America, Asia & International \\
\hline 2012 & Cochrane Report on black cohosh (Cimicifuga ssp.) for menopausal symptoms & Australia \\
\hline 2013 & Corrective reply to Cochrane Report, complete meta-analysis of all nine placebo-controlled studies on efficacy & International \\
\hline 2013 & $\begin{array}{l}\text { Systematic review on efficacy ( } 18 \text { studies) and safety ( } 35 \text { studies); conclusive evidence on efficacy if of licensed } \\
\text { product quality }\end{array}$ & Germany \\
\hline 2014 & Supplementary benefit in myoma patients & China \\
\hline 2015 & Most recent placebo-controlled study; improvement of sleep quality & China \\
\hline 2016 & $\begin{array}{l}\text { Anniversary. } 11,073 \text { patients in } 28 \text { clinical studies on efficacy since } 2000(10,883 \text { investigated with a medicinal } \\
\text { product of licensed quality, } 89 \% \text { thereof iCR) }\end{array}$ & Total \\
\hline
\end{tabular}

erhoben worden waren. Hinweise auf eine Lebertoxizität ergaben sich nicht (international).

Von 2000 bis 2015 wurden insgesamt 28 klinische Studien aus Europa, Amerika und Asien zur Wirksamkeit von CR veröffentlicht. In diesen Studien erhielten 11.073 Patientinnen ein CR-Arzneimittel, 93\% davon iCR. Im Jahr 2013 erschien in Korrektur eines Cochrane Berichts eine vollständige Metaanalyse aller 9 bis dahin veröffentlichten placebokontrollierten Studien und bestätigte eine zuverlässige Wirksamkeit von CR-Arzneimitteln (international) gegen WJB.

Eine aktuelle Studienauswertung ergab, dass sich Myome bei den Frauen verkleinerten, die ihre WJB mit iCR im Gegensatz zu Tibolon behandelten (2014, China). Die jüngste placebokontrollierte klinische Studie zu iCR stammt aus China. Sie zeigte eine Verbesserung der Schlafqualität.

Zukünftige CR-Forschung dürfte sich den Themen Wirkungsmechanismen, möglichen Indikationserweiterungen (z.B. Rezidivprophylaxe bei Brustkrebs) oder Zusatznutzen (z.B. Verbesserung der Frakturraten bei Osteoporose oder kognitiven Fähigkeiten) widmen. Die bisherigen Fakten aus der klinischen
Forschung (KliFo) zu CR bestätigen die Sicherheit und Wirksamkeit bei WJB, liefern aber auch wertvolle Ansatzpunkte hinsichtlich Zusatznutzen, Wirkmechanismen und mehr.

\section{Introduction}

The current issue of the Wiener Medizinische Wochenschrift is dedicated to therapy with products containing herbal ingredients. Rigorously and rationally investigated herbal medicinal products are available for use in humans. Examples thereof are products containing herbal medicinal preparations (extracts) made from the rhizome of Cimicifuga racemosa (L.) Nutt. (CR, synonym for the botanical reclassification name Actaea racemosa L.), Traubensilberkerze, Black cohosh). 60 years ago, in 1956, the career of the first controlled regular medicinal product using this raw material commenced after centuries of its use in North American folk medicine. During these 60 years, extracts made from CR have gained worldwide importance as therapy for menopausal symptoms. In consideration of this anniversary, the current article 
Table 2 Kupperman Menopause Index (KMI). Original wording, coding and example [7, 8]

\begin{tabular}{|l|l|l|l|}
\hline Symptoms & Factor & Severity & $\begin{array}{l}\text { Numerical } \\
\text { Conversion }\end{array}$ \\
\hline Vasomotor & 4 & $+=3$ & 12 \\
\hline Paraesthesia & 2 & $\mathrm{M}=2$ & 4 \\
\hline Insomnia & 2 & $\mathrm{M}=2$ & 4 \\
\hline Nervousness & 2 & $\mathrm{~S}=1$ & 2 \\
\hline Melancholia & 1 & $0=0$ & 0 \\
\hline Vertigo & 1 & $0=0$ & 0 \\
\hline Weakness (fatigue) & 1 & $\mathrm{M}=2$ & 2 \\
\hline Arthralgia and myalgia & 1 & $\mathrm{~S}=1$ & 1 \\
\hline Headaches & 1 & $+=3$ & 3 \\
\hline $\begin{array}{l}\text { Palpitation } \\
\text { Formication }\end{array}$ & 1 & $\mathrm{M}=2$ & 2 \\
\hline $\begin{array}{l}\text { Menopausal index } \\
\text { Code }\end{array}$ & & $\mathrm{S}=1$ & 1 \\
\hline $\begin{array}{l}0-\text { none }=0 \\
\mathrm{~S}-\text { slight }=1\end{array}$ & & & 31 \\
\hline $\begin{array}{l}\mathrm{M}-\text { moderate }=2 \\
+- \text { marked }=3\end{array}$ & & & \\
\hline
\end{tabular}

describes the progress of clinical research evidence on CR during the decades since its official birthdate (Table 1).

\section{Menopausal symptoms}

More than 1.2 billion women in the world will go through menopause by the year 2030 [1]. For a few women, this natural process of aging runs its course asymptomatically, while approximately four out of five women suffer from MPS; this includes MPS caused by surgery, chemotherapy or pelvic radiation. Worldwide, between 50 and 85\% of these women experience severe and disabling symptoms, which significantly affect their wellbeing and quality of life [1-3]. MPS comprise hot flushes and (night) sweats, as well as sleep disturbances associated with these symptoms. Many women also suffer from psychological symptoms such as mood disorders, nervousness and irritability. The duration of these bothersome menopausal symptoms is estimated to be about 8 to 12 years $[4,5]$. These are important reasons for seeking medical attention and for receiving therapy.

\section{Product birthdate 1956}

The first medicinal product produced from black cohosh has been available since 1956 (Remifemin ${ }^{\circledR}$ ). Two galenic formulations for oral intake were launched: tablets containing the isopropanolic extract iCR and a solution containing an ethanolic extract. Shortly thereafter, the first publication described clinical experiences in treating climacteric complaints with the new product [6]. At about the same time, Kupperman established his Menopause Index (KMI, 1953-1959) [7, 8]. It is calculated as the sum of severity coefficients
Table 3 Observational clinical studies on Cimicifuga racemosa during the first decade after launch of Remifemin ${ }^{\circledR}$. (A reference list of these old studies is available from the author on request)

\begin{tabular}{|l|l|}
\hline Author, year of publication & No. of patients \\
\hline Kesselkaul, 1957 & 62 \\
\hline Krämer and Geisenhofer, 1958 & 252 \\
\hline Schotten, 1958 & 22 \\
\hline Földes, 1959 & 82 \\
\hline Stefan, 1959 & 94 \\
\hline Stiehler, 1959 & 53 \\
\hline Brücker, 1960 & 517 \\
\hline Görlich, 1960 & 88 \\
\hline Heizer, 1960 & 110 \\
\hline Starfinger, 1960 & 105 \\
\hline Görlich, 1962 & 258 \\
\hline Langfritz, 1962 & 73 \\
\hline Schildge, 1964 & 135 \\
\hline Total & 1810 \\
\hline
\end{tabular}

of the 11 most common symptoms with assigned symptom-specific weight factors (Table 2). The KMI has since been used in numerous clinical studies, also with iCR.

\section{Clinical studies in the 50 s to the 70 s}

From the 50 s to the 70 s, clinical research on CR followed the common practice of documenting and publishing clinical findings. Practicing gynaecologists and general practitioners, as well as outpatient departments of hospitals documented their experiences per patient on simple case record forms reflecting medical routine. Thirteen publications with a total of 1810 patients resulted from these systematic clinical observations (Table 3). However, their relevance for the total body of evidence on CR has decreased due to the availability of new evidence complying with modern standards for clinical studies.

\section{Changes in the 80 s towards controlled studies}

Whereas the German Medicines Act from 1961 obliged manufacturers to notify any medicinal product to a list only, the thoroughly revised German Medicines Act from 1976 enacted the manufacturer's obligation to provide proof of quality, safety and efficacy of existing and new medicinal products. A transition period was granted for existing drugs until 1990. In the first years after this new legislation, in-depth discussions were held to figure out how to prove these three aspects. Besides the scientific necessities, this debate also included emotional aspects such as the accusing headline on the cover page of the journal Der Spiegel in 1978, stating "Menschenversuche in deutschen Krankenhäusern" (Experiments on Humans in Ger- 
Table 4 Menopause Rating Scale (MRS-I). The investigator assesses each of ten items on a scale ranging from 0 (no complaints) to 1 (severe symptoms) in increments of 0.1 . Subsequently to the original scale [14], subscores were established by factor analyses [15]. Total score and subscores are calculated as the mean of the comprising items

\begin{tabular}{|c|c|c|c|}
\hline Item & Pertaining to subscore & Symptom group & Climacteric symptoms \\
\hline 1 & HOT FLUSHES & Hot flushes, sweating & Sensation of rising heat, outbreaks of sweating (frequency/intensity per $24 \mathrm{~h}$ ) \\
\hline 2 & SOMA & Cardiac symptoms & Palpitations, racing heartbeat, irregular beats, tightness in chest \\
\hline 3 & HOT FLUSHES & Sleep disorders & $\begin{array}{l}\text { Difficulty in falling asleep, difficulty in remaining asleep through the night, waking } \\
\text { too early }\end{array}$ \\
\hline 4 & PSYCHE & Depressive moods & Despondency, sadness, tearfulness, lack of drive, mood fluctuations \\
\hline 5 & PSYCHE & Nervousness, irritability & Nervousness, inner tension, aggressivity \\
\hline 6 & PSYCHE & Impaired performance/memory & Susceptibility to physical and mental exhaustion, poor concentration, forgetfulness \\
\hline 7 & ATROPHY & Disorders of sexuality & Reduced libido, sexual activity and satisfaction \\
\hline 8 & ATROPHY & Urinary symptoms & Symptoms during urination, frequent need to pass urine, accidential incontinence \\
\hline 9 & ATROPHY & Vaginal dryness & Feeling of dryness of the vagina, symptoms during sexual intercourse \\
\hline 10 & SOMA & Joint and muscle symptoms & Pain predominantly affecting the finger joints, rheumatic symptoms, itching \\
\hline
\end{tabular}

man Hospitals; http://www.spiegel.de/spiegel/print/ d-21112940.html). Scientific societies discussed possible clinical study designs from methodological perspectives, e.g. the German Association of Medical Documentation, Informatics and Statistics (GMDS), who dedicated their annual congress to the motto “Therapy Studies-Planning, Realization, Results, Impact” in 1981. Medical scientists and biometricians stated to appreciate randomized controlled trials (RCTs) which appropriately followed in the 1980s for numerous medicinal products, including head-tohead-studies of iCR against reference therapies [9, 10]. When answers to the methodological question "how" seemed to have become settled, first detailed rules enacted a regulatory framework for clinical trials, i. e. from 1985 to 1987, the German Ministry of Health established standards on how to conduct clinical trials for drugs, i. e. medicinal products [11]. Accordingly, the first double-blind, randomized, placebocontrolled clinical trial with CR was also conducted during these years (report 1986, publication 1987, Germany) [12]. This study investigated iCR for its efficacy as measured by the KMI in 80 patients. It revealed a significant superiority of iCR to placebo for alleviating climacteric complaints in the 12-week treatment period, with an onset of efficacy before the first post-baseline visit at 4 weeks [12].

Consequently, the German Commission E approved a positive benefit-risk balance of Cimicifuga racemosa for the treatment of climacteric neurovegetative complaints [13].

\section{GCP and the MRS enter the stage in the 90s}

Good Clinical Practice (GCP) first came into effect in Europe in 1991 and was harmonized by the International Conference(s) of Harmonization (ICH) in 1996 (http://www.ich.org/fileadmin/Public_Web_ Site/ICH_Products/Guidelines/Efficacy/E6/E6_R1_ Guideline.pdf). GCP is an international ethical and scientific quality standard for designing, conducting, recording and reporting trials that involve the par- ticipation of human subjects. Compliance with this standard provides public assurance that the rights, safety and wellbeing of trial subjects are protected and are consistent with the principles that have their origin in the Declaration of Helsinki, and that the clinical trial data are credible. Although it started as a guideline, it was subsequently implemented to mandatory law by GCP directives of the EU council (2001/20/EC) and the EU commission (2005/28/EC).

In 1994, Hauser published his Menopause Rating Scale MRS as a new tool to measure menopausal symptoms [14]. This was a reaction to criticism of the KMI regarding its weighing of symptoms and the incompleteness of its profile of menopausal symptoms. The MRS used a vocabulary of modern language to describe the symptoms assessed by the ten items of the score (Table 4 ). It took another 6 years to make this new scale ripen. In particular, an additional advantage arose with the establishment of the four MRS-I subscores by factor analysis in a large-scale clinical study in several thousand patients in 2000 ([15]; Table 4). Additionally, a self-assessment version appeared as MRS-II [16] and is meanwhile available in 27 languages.

The first GCP compliant clinical study with black cohosh in 1995 investigated iCR in a multicentre setting in Poland and was dedicated to the question of the dose-efficacy relationship. 152 patients suffering from menopausal complaints were randomly assigned to the treatment groups and assessed using the KMI and routine safety parameters including laboratory parameters. Daily doses of iCR extract of up to $127 \mathrm{mg}$ CR proved to be safe and did not influence oestrogenic parameters such as luteinizing hormone ( $\mathrm{LH})$, follicle stimulating hormone (FSH), serum oestradiol (E2), sex hormone-binding globulin (SHBG), prolactin or vaginal cytology [17]. Without differentiating according to menopausal status, iCR extract from $40 \mathrm{mg}$ CR already showed sufficient efficacy in terms of significant improvement of the KMI in comparison to baseline [17]. The response rates $(\mathrm{KMI}<15)$ were 72 and $90 \%$ after 3 and 6 months of treatment, respectively. However, 
perimenopausal women profited more from iCR extract from $127 \mathrm{mg}$ CR than from $40 \mathrm{mgCR}$ [18].

\section{Several placebo-controlled or reference-con- trolled studies in the 2000s}

The second double-blind randomized placebo-controlled clinical study for iCR followed from 2002 to 2005, in a multicentre setting in Germany. 304 patients suffering from menopausal complaints participated and were assessed using the MRS, its MRS subscores and routine safety parameters [19]. In addition proving efficacy again, this study revealed factors that influence efficacy and found first subtle hints of a supra-hypothalamic CNS influence of iCR [19]. Women during their first years of menopausal complaints showed a better superiority to placebo in terms of improvement of their symptoms than those who had been suffering from their complaints for several years [19]. The effect size was 0.03 to 0.05 MRS units, which is similar to HT study results $(0.036$ MRS units, see below), thus showing its clinical relevance. Besides superiority in the MRS total score as the primary efficacy endpoint, the MRS subscore "HOT FLUSHES" (also named vasomotor symptoms, VMS) was the most prominent set of symptoms sensitive to improvement by iCR. This "key competence" of iCR comprises the MRS description "hot flushes, sweatings and associated sleep disorders" (Table 4). Adverse events and other safety parameters were similar in both treatment groups [19].

At approximately the same time, the first placebocontrolled study with a Cimicifuga product from an ethanolic extract (Klimadynon ${ }^{\circledR}$ ) was performed in the Czech Republic and published in 2003. Only 62 patients were evaluable for efficacy after having been randomly allocated to receive a placebo, the CR extract or hormone therapy. Unfortunately for the investigators, their CR effect (0.037 MRS units) narrowly missed the significance level due to this too small sample size. However, the particular contribution of this study is that it strengthens the MRS by establishing the MRS-based effect size of hormone therapy (HT) for menopausal symptoms, i.e. 0.036 MRS units compared to placebo [20]. Additionally, CR and HT led to beneficial effects on serum parameters of bone metabolism and an increase in vaginal superficial cells, but, in contrast to HT, there was no CR effect on endometrial thickness.

Subsequent controlled studies published in 2005 and 2007 that compared iCR (Remifemin ${ }^{\circledR}$ ) with other MPS therapies showed no relevant differences in efficacy compared to oestradiol patches [21] and tibolone, but iCR was superior regarding safety [22]. In detail, the comparison to oestradiol patches [21] for a 3-month treatment was performed in 64 patients in Italy. The efficacy parameters (hot flush diary, Greene scale) significantly improved over time, without relevant differences between the treatment groups. Serum hormone levels (LH, FSH, oestradiol, prolactin), safety-relevant serum enzymes for liver function and endometrial thickness did not change over time in the iCR-group. Interestingly in contrast, LDL levels (low density lipoprotein) decreased and HDL levels (high density lipoprotein) increased over time in the iCR-group [21]. The comparison of iCR to tibolone [22] was a double-blind, randomized controlled study and the first study on a CR-based herbal medicinal product with licensed pharmaceutical quality in an Asian population, particularly in China. This study was necessary and pivotal for the regulatory approval of iCR in that country. As yet, no other CR extract has been approved by the Chinese regulatory authority (SFDA). 244 patients were included and applied either iCR or tibolone for 3 months. The well-established Chinese version of the KMI served as the efficacy parameter and significantly improved over time, without relevant differences between the treatment groups, even for moderate to severe symptoms. The KMI responder rate was also similar in both groups ( $84 \%$ and $85 \%)$. The safety evaluation showed a good safety and tolerability profile for both groups; however, there was a significantly lower incidence of adverse events $(p<0.0001)$ in favour of the herbal treatment. In particular, none of the postmenopausal iCR patients experienced vaginal bleeding in contrast to tibolone (17 cases). As a result, the primary endpoint (benefit-risk balance), which had been prespecified in the study protocol as the combination of the Mann-Whitney values of the KMI and the frequency of adverse events, also showed superiority of iCR to tibolone ( $p=0.009)$.

In 2008, another CR product (Remixin $\left.{ }^{\circledR}\right)$ contributed a controlled study comparing CR to fluoxetine, with inferiority in the psychological component of the MPS and superiority in the KMI (Turkey) [23].

\section{It's in the brain: pathophysiology of hot flushes/ sweating and iCR effects seem to match}

Pharmaceutical products with proven efficacy, safety and reproducible pharmaceutical quality are a matter of interest regarding their mode of action. Hence, iCR was also investigated for pharmacodynamic effects. Several preclinical studies argue for an oligo-factorial mode of action of CR extracts (see below), including effects on CNS-relevant systems. Clinically, a milestone was reached in 2005 by a poster at the annual conference of the North American Menopause Society and 2008 by the corresponding full publication, i. e. a clinical study proved a CNS influence of iCR using positron-emission tomography (USA) [24]. The authors had treated postmenopausal women with iCR for 3 months and found changes in $\mu$-opioid receptor availability in distinct brain regions. In detail, iCR increased opioid-binding in regions known to be relevant for emotional and cognitive functions (thalamus, nucleus accumbens, posterior and anterior cingulum) 
and decreased the opioid binding in the dorsoanterior cingulum and the anterior insular cortex. Although these regions are known to be oestrogen-sensitive, the iCR effects were not oestrogenic because iCR alone did not change the frequency of the LH pulse, whereas iCR in combination with the opioid antagonist naloxone did decrease this frequency [24].

Interestingly and consistently, some of these regions were identified during those years as also being in the pathophysiology of hot flushes and sweating [25]. In detail, Freedman et al. compared brain activation in symptomatic postmenopausal women and asymptomatic eumenorrheic women in their controlled laboratory study using magnetic resonance imaging. Areas of activation during hot flashes in symptomatic women included the insula and anterior cingulate cortex. Sweating in eumenorrheic women was associated with activity in the anterior cingulate and superior frontal gyrus. The authors concluded that thermoregulation in humans appears to be represented in a distributed cortico-subcortical network rather than in a single localized structure [25].

This matching of Reame's [24] and Freedman's data [25] accords with preclinical results. CR/iCR contains substances which bind to serotonin, dopamine, GABA and $\mu$-opioid brain receptors leading to receptor-mediated functional activity [26-30]. CR/iCR modulates the ratio of cerebral monoamines and metabolites [31] as well as brain activity (EEG) [32], i. e. serotonergic and dopaminergic systems and $\mu$-opioid receptor availability [29]. iCR ameliorates an ovariectomy-induced decrease in a serotonin dorsal raphe-preoptic hypothalamus pathway [33]. iCR recovered the activity of neurons in the preoptic area in the hypothalamus which were impaired by oestrogen deprivation $[34,35]$. After iCR treatment, neurons recovered their sensitivity to temperature changes and were identified as active neurons [34]. These data suggest that alleviation of VMS by CR/iCR is not caused by oestrogen-agonistic effects. The hypothesis of an association between CNS receptor-mediated effects and an efficacious relief of VMS has become more plausible, since iCR binds to CNS receptors and modulates brain function and metabolism involved in thermoregulation. Future research is needed to verify this hypothesis.

\section{Upscale of sample size and duration of clinical studies}

The largest clinical study with CR to date $(N=6141 \mathrm{fe}$ male patients) was presented at the annual conference of the German Menopause Association in 2005 and fully published in 2007. For the first time, it included over 12 months of safety data on patients $(N=736)$ [36]. 1287 gynaecologists [36] in Germany included women suffering from and treated for their VMS or climacteric mood symptoms or both into this prospec- tive, controlled, open-label, non-interventional study. iCR was compared with the combined product containing iCR and St. John's wort (HP). Patients were followed up for 6 months, optionally 12 months if treated for this duration. The primary effectiveness variable was the MRS subscore "psyche" at month 3 and evaluated by ANCOVA (analysis of covariance). This MRS subscore comprises climacteric depressive moods, nervousness, irritability and impaired cognitive functions (Table 4). The total MRS score improved with both regimens during the first 3 months, further improved over time during the subsequent 3 months, and did not change anymore during months 6 to 12 . iCR-HP was superior to iCR in the primary endpoint, i. e. showed an additional benefit in the psychological component of MPS, i. e. climacteric mood complaints [36]. The study did not find any suspicion of liverrelated side effects. The rate of possibly treatment-related adverse events was $0.16 \%$, all non-serious. The global assessment of tolerability revealed this to be good or very good in more than $90 \%$ of the patients [36].

Proof of efficacy for this combination was also achieved using a double-blind, randomized, placebocontrolled study (2006) [37]. The study included 301 patients for treatment with the iCR-HP combination for 4 months in Germany and found a 50\% MRS improvement by this herbal treatment in comparison to $20 \%$ in the placebo group $(p<0.001)$. The study additionally assessed the climacteric mood complaints using the Hamilton Depression Scale (HAMD) and revealed a $42 \%$ HAMD improvement with the iCRHP medication in comparison to $13 \%$ in the placebogroup $(p<0.001)$. The frequency and pattern of adverse events, safety laboratory results and the clinical global impression of tolerability were similar in both treatment groups [37].

\section{Clinical safety at endometrium and breast}

In 2006, a clinical study on safety at the endometrium with a 12-month CR therapy followed. This prospective, open-label, multicentre study in Poland and the Czech Republic included 400 patients, assessed them by ultrasonography and did not find any case of endometrial hyperplasia or any increase of the mean of the endometrial thickness over time [38].

The safety of iCR on breast tissue was also substantiated with a clinical study: in 2007 alone $(N=64)$ [39] and in 2011 in a meta-analysis together with a preceding study comparing placebo $(N=53)$, HT $(N=$ 43) and tibolone $(N=49)$ [40]. Both studies were performed in the same setting at the Karolinska Hospital in Stockholm, Sweden. Blinded observers compared the baseline status of mammography (breast density) and fine-needle aspiration biopsy (breast cell proliferation assessed as the frequency of Ki-67-positive cells) with the status after 6 months of treatment. Breast density remained unchanged in the placebo group 
and the iCR group ( $0 \%$ and no case more than $5 \%$ ) but significantly increased $(p<0.001)$ in the HT group $(+14.3 \%$ and 27 cases more than $5 \%$ ) and the tibolone group $(+2.3 \%$ and 10 cases more than $5 \%)$ [40]. Furthermore, there was no increase in breast cell proliferation upon iCR treatment, i.e. no increase in the mean/median proportion of Ki-67-positive cells [39]. The mean/median change in ultrasonographically investigated endometrial thickness was 0 [39]. These clinical study data on iCR do not give any indication of adverse effects on healthy breast tissue or any endometrial safety concerns [39].

In 2007, a pharmacoepidemiological cohort study demonstrated a 4.5 year longer recurrence-free survival after breast cancer for iCR users [41]. This study examined the data of breast cancer patients treated at general, gynaecological and internal facilities linked to a medical database in Germany. The impact of treatment with iCR following diagnosis was analysed by Cox proportional hazards models, controlling for age and other confounders. Of 18,861 patients, a total of 1102 had received an iCR therapy (either iCR alone or the iCR-HP combination). The mean overall observation time was 3.6 years. iCR exposure was not associated with an increase in the risk of recurrence but was associated with prolonged disease-free survival. 2 years after initial diagnosis, $14 \%$ of the control group had developed a recurrence, while the iCR group reached this proportion after 6.5 years. The primary Cox regression model controlling for age, tamoxifen use and other confounders demonstrated a protractive effect of iCR on the rate of recurrence (hazard ratio $0.83, p=0.039$ ). This effect remained consistent throughout all variations of the statistical model, including subgroup analyses. TNM status was unknown but did not bias the iCR treatment decision (due to climacteric complaints) as investigated separately. Once in a while, this study is criticized for this TNM uncertainty in the dataset. However, due to the independency of the treatment decision from the TNM status, the missing of TNM information is not a source of bias for the comparison of iCR-users with nonusers regarding the endpoint of this study. Notably, the missing TNM data even impaired the power of the study to detect any group difference on a significant level because its impact cannot be deducted from the overall variance of the endpoint. But if a detected difference is already significant, such impairment of power becomes irrelevant. In contrast, if endpoint and reason for treatment allocation depend on the same confounder, this can cause bias and should not suffer from missing data and should be included into the regression model (cofactor/covariate or stratification). This applies for the confounders age and tamoxifen use, and the study's analyses appropriately cared for this [41]. In particular, the beneficial recurrence protractive effect of iCR occurred in tamoxifenusers and also in tamoxifen-nonusers [41].

\section{HMPC monograph and meta-analyses}

In 2010, the HMPC attested the well-established use of medicinal products containing CR extract based on previously published studies on menopausal symptoms [42]. An essential precondition of regulatory authorities' approval of products based on such monographs is the proof and approval of its product-specific pharmaceutical quality. The pharmaceutical characteristics of HMPC-accepted herbal medicinal products made from Cimicifuga racemosa comprise the "quantitative and qualitative composition" requiring "dry extract (drug-extract ratio, DER 5-10:1), extraction solvent ethanol 58\%" or "dry extract (DER 4.5-8.5:1), extraction solvent ethanol 60\%" or "dry extract (DER 6-11:1), drug extraction solvent isopropanol 40\%". Notably, the HMPC monograph does not limit the length of the use of CR extracts, but after 6 months of therapy, a medical professional should be consulted. The reason behind this is that women who usually suffer from MPS are in a certain age range when they should see their doctor anyway, in order to avoid overseeing any serious disease. Also, breast cancer patients are not excluded from the treatment of MPS with CR as long as a medical professional is consulted. This is actually a matter of course, because physicians who treat cancer patients should know every medicinal product their patients take [42].

The clinical data on the safety of CR extracts in endometrium, liver, breast and breast cancer were further augmented by numerous supportive preclinical studies in animals and cell cultures. For preclinical details, refer to the assessment report of the HMPC monograph on CR [42].

In 2011 the first meta-analysis was dedicated to the topic of liver safety [43]. In all five controlled clinical studies with iCR available from any country at that time, the liver function test values were summarized where they had been raised. The dataset comprised 1117 peri- or postmenopausal women who treated their symptoms with iCR for 3 to 6 months. The dosages of the extracts corresponded to $40-128 \mathrm{mg}$ herbal substance per day. The meta-analysis did not find any group difference regarding the safety-relevant serum enzymes for liver function, particularly also neither at the highest dosage nor upon the longest duration of exposure. Evidence of liver toxicity was not found [43]. This accords with the safety results of a recent systematic review [44] and its update [45], which did not find any case of hepatotoxicity among the more than 12,000 patients in all clinical studies on the safety of CR-based study medication.

This systematic review [44] and its update [45] certified an Oxford level of evidence 1a (safety) or 1b (efficacy) and grade of recommendation A for the iCR, with lower level of evidence and grade of recommendation for other CR extracts. Particularly the efficacy aspect of this systematic review deserves further at- 
Fig. 1 Efficacy data sets from clinical studies on Cimicifuga racemosa $(C R)$ from 2000 to 2015. iCR isopropanolic extract of $\mathrm{CR}$ rootstock, HP Hypericum perforatum, LOEOxford Level of Evidence, GR Oxford Grade of Recommendation

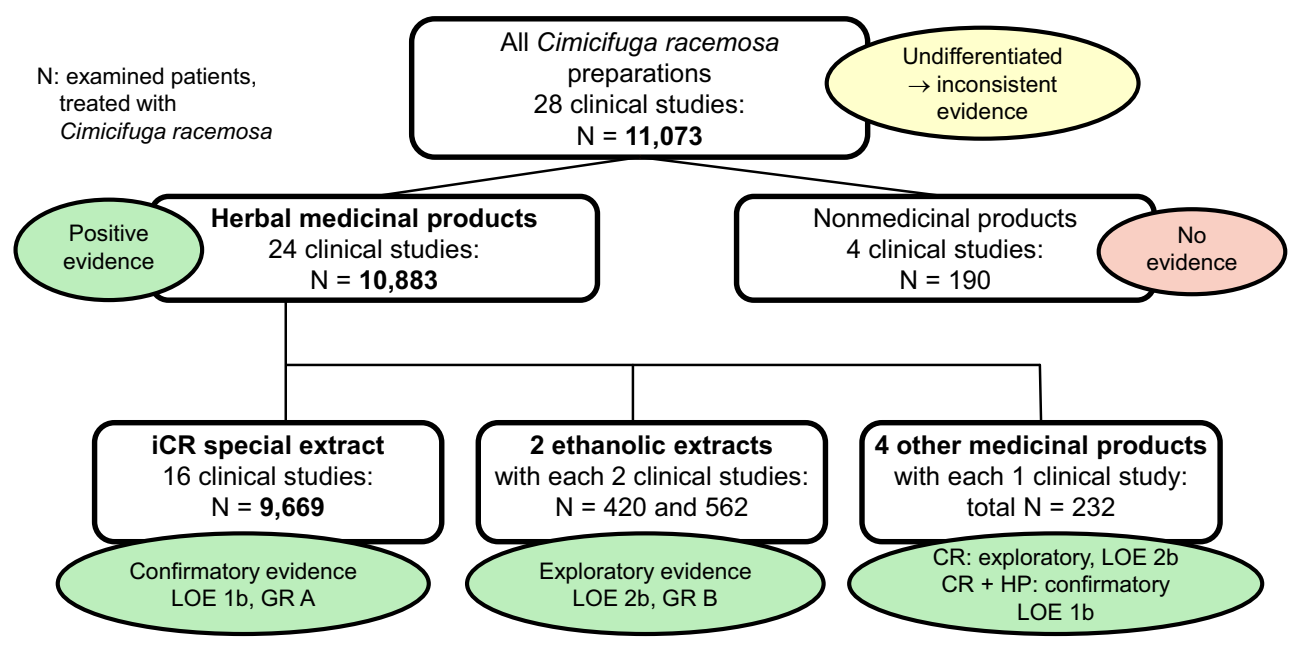

Table 5 Placebo-controlled studies on Cimicifuga racemosa for alleviating natural menopausal complaints. For bibliographic details of these studies see Beer et al. [47]

\begin{tabular}{|c|c|c|c|c|}
\hline Author, year & $\begin{array}{l}\text { Licensed medicinal } \\
\text { product }\end{array}$ & Number of patients & $\begin{array}{l}\text { Standardized difference in } \\
\text { means }\end{array}$ & $95 \%$ confidence interval \\
\hline Frei Kleiner 2005 & Yes & 122 & -0.090 & -0.461 to 0.281 \\
\hline Geller 2009 & No & 43 & 0.170 & -0.408 to 0.748 \\
\hline Amsterdam 2009 & No & 28 & 0.430 & -0.286 to 1.146 \\
\hline Newton 2006 & No & 164 & -0.270 & -0.578 to 0.038 \\
\hline 0smers 2005 & Yes & 286 & -0.394 & -0.626 to -0.162 \\
\hline Stoll 1987 & Yes & 50 & -1.020 & -1.586 to -0.454 \\
\hline Wuttke 2003 & Yes & 40 & -0.639 & -1.260 to -0.018 \\
\hline Kaiser 2008 & Yes & 120 & -0.617 & -0.975 to -0.259 \\
\hline Li Yilin & Yes & 77 & -0.792 & -1.246 to -0.338 \\
\hline $\begin{array}{l}\text { Meta-analysis summary of } \\
\text { efficacy }\end{array}$ & Any & 930 & -0.385 & $\begin{array}{l}-0.514 \text { to }-0.255 \\
(p<0.0001)\end{array}$ \\
\hline
\end{tabular}

tention, because the reviewer figured out a very important key point for interpretation of efficacy results of all recent studies: conclusive evidence on efficacy if of licensed-product quality, inconclusiveness only if other quality was investigated. From 2000 to 2015, a total of 29 clinical studies in Europe, America and Asia were published on the efficacy of CR. In these studies 10,049 patients received a CR-based medicinal product, 93\% thereof iCR (Fig. 1; [44-46]).

In 2013 a corrective reply to the Cochrane Report on black cohosh-Cimicifuga ssp. in 2012 presented a complete meta-analysis of all nine placebo-controlled studies published till then; the report confirmed the reliable efficacy of CR-based medicinal products. The result of this meta-analysis estimates the standardized effect size in comparison to placebo to be 0.385 standard deviations $(p<0.0001$; Table 5 ; [47]).

\section{Supplemental benefits and upfront potential}

A recent study analysis evidenced that in women who were treated with iCR for MPS, the myomas shrank in size compared to therapy with tibolone (2014) [48]. The dataset of this supplemental analysis was a sub- set of the randomized controlled study comparing iCR and tibolone in menopausal complaints in China [22] and comprised all 62 patients with at least one uterine fibroid at onset of treatment. The size of the fibroids had been measured by transvaginal ultrasonography. The median myoma volume decreased with iCR for 3 months by as much as $-30 \%(p=0.016)$, but increased with tibolone by $+4.7 \%$. The latter corresponds to the $+4.4 \%$ that can be expected for untreated myoma patients of similar age.

Data from four clinical trials [49-52] hint at beneficial effects of CR on bone metabolism and bone mineral density which might help to reduce the cumulative dose of HT for prophylaxis of osteoporosis.

The latest placebo-controlled clinical study with iCR came from China. It showed the improvement of sleep quality in postmenopausal women with sleep disturbances [53].

\section{Adverse drug reactions}

The profile of adverse drug reactions (ADR) which emerged from all the clinical studies and from pharmacovigilance monitoring is summarized in the package insert leaflet and in the summary of product cha- 
racteristics of licensed medicinal products according to the HMPC monograph and comprises for iCR: Rarely: gastrointestinal symptoms, allergic skin reactions, facial or peripheral oedema, increase of liver enzymes in the serum, increase of body weight. Very rarely, cases of liver toxicity were reported during the use of Cimicifuga products. However, a causal relationship has not yet been confirmed.

To date, none of all the clinical studies on the safety of CR-based study medication found any case of hepatotoxicity among their more than 12,000 participating patients.

\section{Long-term treatment}

The duration of use of medicinal products intended for non-life-threatening diseases is directly linked to a positive risk-benefit assessment based on clinical data over distinct exposure periods according to the ICH-E1 guideline (http://www.ema.europa.eu/docs/ en_GB/document_library/Scientific_guideline/2009/ 09/WC500002747.pdf). For a long-term treatment, this guideline requires that the number of patients monitored for ADR in clinical studies:

- should be at least 300-600 treated for 6 months. This principle is fulfilled already by the 6141 patients exposed to iCR for at least 6 months in the study by Briese et al. [36] and several additional hundreds of patients in all the other clinical studies on iCR (for a complete list see [44] and its update [45]).

- should be at least 100 treated for 12 months. This principle is fulfilled by the 736 patients exposed to iCR for 12 months in the study by Briese et al. [36].

- should be at least 1500 treated for any duration. This principle is fulfilled by the total number of about 12,000 patients exposed to iCR in interventional and non-interventional clinical studies [36, 44, 45].

One may discuss whether the chapter "exceptions" in ICH-E1 applies, e.g. if concerns had arisen from animal studies. However, the chronic toxicity studies available for the iCR products did not reveal such concern (unpublished preclinical study reports available at the regulatory authorities who granted marketing authorizations of these products).

Sufficient clinical study data are available, at least for iCR among the CR extracts, to fulfil the ICH-E1 set of principles for a safe long-term treatment (chronic or repeated intermitted use longer than 6 months).

Independently from the sufficient extent of preclinical and clinical data supporting the safe use of black cohosh, all menopausal women should seek routine medical advice every 6 to 12 months, to avoid other relevant diseases being overlooked.

\section{Future}

Future CR research may be dedicated to such topics as: mechanisms of action, possible extension of indications (e.g. prophylaxis for breast cancer recurrence) or additional uses (e.g. improvement of osteoporosis fractures or cognitive abilities). To date, the results of clinical research with CR confirm its safety and efficacy for menopausal symptoms and also provide valuable insights into additional uses, the mechanism of action and more.

\section{Conclusion}

The 60 years since the launch of the first CR-based medicinal product have included preclinical and clinical research (89\% of patients investigated used iCR) showing:

- Efficacy for menopausal complaints, if licensed medicinal product quality.

- Beneficial and usable already in symptomatic premenopausal patients.

- Possible supplemental benefits (increase of diseasefree survival after breast cancer, adjuvant prophylaxis of osteoporosis, shrinkage of myoma, other effects).

- Safety (iCR fulfils the regulatory requirements on long-term treatment, is safe at oestrogen-sensitive tissues such as breast, uterus or tumours, did not impair tamoxifen or aromatase inhibitors, did not show hepatotoxicity in clinical studies).

- Differential effects in the periphery and influence on CNS regions responsible for thermoregulation, mood and sleep.

Acknowledgements Many thanks to the thousands of women whose data contributed to the current body of evidence on CR for the benefit of future patients.

Conflict of interest H.-H. Henneicke-von Zepelin is an employee of the manufacturer of Remifemin ${ }^{\circledR}$. However, the author declares that this employment has not biased the scientific presentation of facts in the current publication.

Open Access This article is distributed under the terms of the Creative Commons Attribution 4.0 International License (http://creativecommons.org/licenses/by/4.0/), which permits unrestricted use, distribution, and reproduction in any medium, provided you give appropriate credit to the original author(s) and the source, provide a link to the Creative Commons license, and indicate if changes were made.

\section{References}

1. WHO Scientific Group. Research on the menopause in the 1990s. World Health Organ Tech Rep Ser. 1996;866:1-107.

2. Utian WH. Psychosocial and socioeconomic burden of vasomotor symptoms in menopause: A comprehensive review. Health Qual Life Outcomes. 2005;3:47.

3. Skurnick JH, Weiss G, Goldsmith LT, Santoro N, Crawford S. Longitudinal changes in hypothalamic and ovarian function in perimenopausal women with anovulatory cycles: Relationship with vasomotor symptoms. Fertil Steril. 2009;91(4):1127-34.

4. Politi MC, Schleinitz MD, Col NF. Revisiting the duration of vasomotor symptoms of menopause: A meta-analysis. JGen Intern Med. 2008;23(9):1507-13. 
5. Freeman EW, Sammel MD, Lin H, LiuZ, Gracia CR. Duration of menopausal hot flushes and associated risk factors. Obstet Gynecol. 2011;117(5):1095-104.

6. Kesselkaul O. Treatment of climacteric disorders with remifemin. Med Monatsschr. 1957;11(2):87-8.

7. Kupperman HS, Blatt MH, Wiesbader H, Filler W. Comparative clinical evaluation of estrogenic preparations by the menopausal and amenorrheal indices. J Clin Endocrinol Metab. 1953;13(6):688-703.

8. Kupperman HS, Wetchler BB, Blatt MH. Contemporary therapy of the menopausal syndrome. J Am Med Assoc. 1959;171:1627-37.

9. Lehmann-Willenbrock E, Riedel HH. Clinical and endocrinologic studies of the treatment of ovarian insufficiency manifestations following hysterectomy with intact adnexa. Zentralbl Gynakol. 1988;110(10):611-8.

10. Warnecke G. Beeinflussung klimakterischer Beschwerden durch ein Phytotherapeutikum. (Influencing menopausal symptoms with a phytotherapeutic agent). Med Welt. 1985;36:871-4.

11. Bundesministerium Jugend Familie Frauen und Gesundheit. Grundsätze für die Durchführung der klinischen Prüfung von Arzneimitteln. BAnz. 1987, pp 16617-24.

12. Stoll W. Phytotherapeutikum Doppelblindversuch Cimicifuga vs Östrogenpräparat. Therapeutikon. 1987;1:23-31.

13. Commission E. Monograph on Cimicifuga racemosa (L.) Nutt. German Commission E 1989.

14. Hauser GA, Huber IC, Keller PJ, Lauritzen C, Schneider HPG. Evaluation der klimakterischen Beschwerden (Menopause Rating Scale [MRS]).Zentralbl Gynakol. 1994;116:16-23.

15. Schneider HP, Rosemeier HP, Schnitker J, Gerbsch S, Turck R. Application and factor analysis of the menopause rating scale [MRS] in a post-marketing surveillance study of Climen. Maturitas. 2000;37(2:113-24.

16. Potthoff P, Heinemann LAJ, Schneider HPG, Rosemeier HP, Hauser GA. Menopause-Rating-Skala (MRS II): Methodische Standardisierung in der deutschen Bevölkerung. ZentralblGynakol. 2000;122:280-6.

17. Liske E, Hanggi W, Henneicke-von Zepelin HH, Boblitz N, Wustenberg P, Rahlfs VW. Physiological investigation of a unique extract of black cohosh (Cimicifugae racemosae rhizoma): a 6-month clinical study demonstrates no systemic estrogenic effect. J Womens Health Gend Based Med. 2002;11(2):163-74.

18. Henneicke-von Zepelin H, Lin SY, Friede M. Does the optimal dosage of Cimicifuga extract for climacteric complaints depend on the patient's menopausal status? Climacteric. 2002;5:91.

19. Osmers R, Friede M, Liske E, Schnitker J, Freudenstein J, Henneicke-von Zepelin HH. Efficacy and safety of isopropanolic black cohosh extract for climacteric symptoms. Obstet Gynecol. 2005;105(5 Pt 1):1074-83.

20. Wuttke W, Seidlova-Wuttke D, Gorkow C. The Cimicifuga preparation BNO 1055 vs. conjugated estrogens in a doubleblind placebo-controlled study: effects on menopause symptoms and bone markers. Maturitas. 2003;44(Suppl 1):S67-S77.

21. Nappi RE, Malavasi B, Brundu B, Facchinetti F. Efficacy of Cimicifuga racemosa on climacteric complaints: a randomized study versus low-dose transdermal estradiol. GynecolEndocrinol. 2005;20(1):30-5.

22. Bai W, Henneicke-von Zepelin HH, Wang S, Zheng S, Liu J, Zhang Z, et al. Efficacy and tolerability of a medicinal product containing an isopropanolic black cohosh extract in Chinese women with menopausal symptoms: a randomized, double blind, parallel-controlled study versus tibolone. Maturitas. 2007;58(1):31-41.
23. Oktem M, Eroglu D, Karahan HB, Taskintuna N, Kuscu E, Zeyneloglu HB. Black cohosh and fluoxetine in the treatment of postmenopausal symptoms: A prospective, randomized trial. Adv Ther. 2007;24(2):448-61.

24. Reame NE, Lukacs JL, Padmanabhan V, Eyvazzadeh AD, Smith YR, Zubieta JK. Black cohosh has central opioid activity in postmenopausal women: Evidence from naloxone blockade and positron emission tomography neuroimaging. Menopause. 2008;15(5):832-40.

25. Freedman RR, Benton MD, Genik RJ, Graydon FX. Cortical activation during menopausal hot flashes. Fertil Steril. 2006;85(3):674-8.

26. BurdetteJE, Liu J, Chen SN, FabricantDS, Piersen CE, Barker EL, et al. Black cohosh acts as a mixed competitive ligand and partial agonist of the serotonin receptor. J Agric Food Chem. 2003;51(19):5661-70.

27. Powell SL, Godecke T, Nikolic D, Chen SN, Ahn S, Dietz B, et al. In vitro serotonergic activity of black cohosh and identification of $\mathrm{N}$ (omega)-methylserotonin as a potential active constituent. JAgric Food Chem. 2008;56(24):11718-26.

28. Nisslein T, Koetter U, Freudenstein J. In vitro binding of an isopropanolic extract of black cohosh to selected central nervous receptors. Maturitas. 2006;54 S:S65.

29. Rhyu MR, Lu J, Webster DE, Fabricant DS, Farnsworth NR, Wang ZJ. Black cohosh (Actaea racemosa, Cimicifuga racemosa) behaves as a mixed competitive ligand and partial agonist at the human mu opiate receptor. J Agric Food Chem. 2006;54(26):9852-7.

30. Winterhoff H, Spengler B, Christoffel V, Butterweck V, Lohning A. Cimicifuga extract BNO 1055: reduction of hot flushes and hints on antidepressant activity. Maturitas. 2003;44(Suppl 1):S51-S58.

31. Nadaoka I, Watanabe K, Yasue M, Sami M, Kitagawa Y, Mimaki Y. Oral administration of Cimicifuga racemosa extract attenuates immobilization stress-induced reactions. Nat Prod Commun. 2012;7(1):15-8.

32. Garcia de Arriba S, Dimpfel W, Henneicke-von Zepelin $\mathrm{HH}$, Zhang Hui, Bai W, Nolte KU. Isopropanolic Cimicifuga Extract Modulates Brain Activity; Electropharmacogram from Various Brain Areas in Freely Moving Rats (TeleStereo-EEG). Maturitas. 2015;82(3):318.

33. Wang W, Cui G, Jin B, Wang K, Chen X, Sun Y, et al. Estradiol Valerate and Remifemin ameliorate ovariectomyinduced decrease in a serotonin dorsal raphe-preoptic hypothalamus pathway in rats. Ann Anat. 2016;208:31-9.

34. Hui Z, Xiaoyan M, Mukun Y, Ke W, Liyuan Y, Sainan Z, et al. Effects of black cohosh and estrogen on the hypothalamic nuclei of ovariectomized rats at different temperatures. JEthnopharmacol. 2012;142(3):769-75.

35. Ma X, Zhang H, Wang K, Yang L, Qin L, Bai W, et al. Effects of an isopropanolic-aqueous black cohosh extract on central body temperature of ovariectomized rats. JEthnopharmacol. 2011;138(1):156-61.

36. Briese V, Stammwitz U, Friede M, Henneicke-von Zepelin HH. Black cohosh with or without St. John's wort for symptom-specific climacteric treatment-results of a large-scale, controlled, observational study. Maturitas. 2007;57(4):405-14.

37. Uebelhack R, Blohmer JU, Graubaum HJ, Busch R, Gruenwald J, Wernecke KD. Black cohosh and St. John's wort for climacteric complaints: A randomized trial. Obstet Gynecol. 2006;107(2 Pt 1):247-55.

38. Raus K, Brucker C, Gorkow C, Wuttke W. First-time proof of endometrial safety of the special black cohosh extract (Actaea or Cimicifuga racemosa extract) CR BNO 1055. Menopause. 2006;13(4):678-91. 
39. Hirschberg AL, Edlund M, Svane G, Azavedo E, Skoog L von SB. An isopropanolic extract of black cohosh does not increase mammographic breast density or breast cell proliferation in postmenopausal women. Menopause. 2007;14(1):89-96.

40. Lundstrom E, Hirschberg AL, Soderqvist G. Digitized assessment of mammographic breast density-effects of continuous combined hormone therapy, tibolone and black cohosh compared to placebo. Maturitas. 2011;70(4):361-4.

41. Henneicke-von Zepelin HH, Meden H, Kostev K, SchroderBernhardi D, Stammwitz U, Becher H. Isopropanolic black cohosh extract and recurrence-free survival after breast cancer. Int JClin Pharmacol Ther. 2007;45(3):143-54.

42. European Medicines Agency (EMA) Committee on Herbal Medicinal Products (HMPC). Community Herbal Monograph on Cimicifuga racemosa (L.) Nutt., Rhizoma. [EMA/ HMPC/600717/2007]. 25-11-2010.

43. Naser B, Schnitker J, Minkin MJ, de Arriba SG, Nolte KU, Osmers R. Suspected black cohosh hepatotoxicity: No evidence by meta-analysis of randomized controlled clinical trials for isopropanolic black cohosh extract. Menopause. 2011;18(4):366-75.

44. Beer AM, Neff A. Differentiated evaluation of extractspecific evidence on Cimicifuga racemosa's efficacy and safety for climacteric complaints. Evid Based Complement Alternat Med. 2013;2013:860602.

45. Beer AM. Cimicifuga racemosa bei klimakterischen Beschwerden. ZPhytother. 2015;36(01):10-7.

46. WuX. Remifemin improve gynecological malignant tumor postoperative patients of menopause syndrome for the clinical research. Dalian: Medical University; 2011. Master Degree Thesis.

47. Beer AM, Osmers R, Schnitker J, Bai W, MueckAO, Meden H. Efficacy of black cohosh (Cimicifuga racemosa) medicines for treatmentofmenopausalsymptoms-comments onmajor statements of the Cochrane Collaboration report 2012 "black cohosh (Cimicifuga spp.) for menopausal symptoms (review)". Gynecol Endocrinol. 2013;29(12):1022-5.

48. Xi S, Liske E, Wang S, Liu J, Zhang Z, Geng L, et al. Effect of Isopropanolic Cimicifuga racemosa extract on uterine fibroids in comparison with Tibolone among patients of a recent randomized, double blind, parallel-controlled study in Chinese women with menopausal symptoms. Evid Based Complement Alternat Med. 2014;2014:717686.

49. Wuttke W, Gorkow C, Seidlova-Wuttke D. Effects of black cohosh (Cimicifuga racemosa) on bone turnover, vaginal mucosa, and various blood parameters in postmenopausal women: a double-blind, placebo-controlled, and conjugated estrogens-controlled study. Menopause. 2006;13(2):185-96.

50. Garcia-Perez MA, Pineda B, Hermenegildo C, Tarin JJ, Cano A. Isopropanolic Cimicifuga racemosa is favorable on bone markers but neutral on an osteoblastic cell line. Fertil Steril. 2009;91(4 Suppl):1347-50.

51. Bebenek M, Kemmler W, von SS, Engelke K, Kalender WA. Effect of exercise and Cimicifuga racemosa (CR BNO 1055) on bone mineral density, 10 -year coronary heart disease risk, and menopausal complaints: The randomized controlled Training and Cimicifuga racemosa Erlangen (TRACE) study. Menopause. 2010;17(4):791-800.

52. Li W, Sun N, Chen X, Lang D, Jin Z. Cimicifuga racemosa for treatment of menopausal symptoms in patients with early endometrial cancer after operation. Acad J Second Mil Med Fre. 2012;33(5):562-4.

53. Jiang K, Jin Y, Huang L, Feng S, Hou X, Du B, et al. Black cohosh improves objective sleep in postmenopausal women with sleep disturbance. Climacteric. 2015;18(4):559-67. 